\title{
EFEKTIVITAS PELATIHAN KEBERSYUKURAN UNTUK MENINGKATKAN \\ KESEJAHTERAAN SUBJEKTIF PADA PENDERITA HIPERTENSI
}

\section{THE EFFECTIVENESS OF GRATITUDE TRAINING TO INCREASE SUBJECTIVE WELL- BEING AMONG HYPERTENSIVE PATIENTS}

\author{
Anisa Rahmanita \\ Qurotul Uyun \\ Rr. Indahria Sulistyarini \\ Fakultas Psikologi dan IImu Sosial Budaya, Universitas Islam Indonesia, Yogyakarta \\ Email: anisarahmanita8@gmail.com
}

\begin{abstract}
The purpose of this study is to examine the effectiveness of gratitude training in increasing life satisfaction and affection level of hypertentive patient. The participants of this study were patients who had hypertention, 40-60 years old, and muslim. The design of this study is quasi-experimental design, wtih pretest-posttest control group desain Data were collected with Subjective well-being Scale (SWLS) from Diener, Emmon, Larsen, and Griffin (1985) and The Positive and Negative Affect Schedule (PANAS) from Watson, Clark, and Tellegen (1988). Analysis data showed that there was a significant difference between SWLS score of experiment and control group $(t=9.624, p=0.000 p<0.01)$ and PANAS score $(t=10.931$, $p=0.000 p<0.01$.
\end{abstract}

Key words : gratitude training, subjective well-beling, life satisfaction, affection, hypertention

\begin{abstract}
ABSTRAK
Penelitian ini bertujuan melihat efektivitas pelatihan kebersyukuran untuk meningkatkan kepuasan hidup dan nilai afek pada penderita penyakit hipertensi. Subjek dalam penelitian ini adalah para penderita hipertensi, berusia 40-60 tahun, dan beragama Islam. Desain penelitian adalah quasi eksperimen (pretestposttest control group desain dan tindak lanjut). Pengukuran kesejahteraan subjektif menggunakan skala kepuasan hidup (SWLS) dari Diener, Emmon, Larsen, and Griffin (1985) dan skala afek (PANAS) dari Watson, Clark, and Tellegen (1988). Hasil penelitian ini menunjukkan bahwa terdapat perbedaan yang signifikan pada nilai kepuasan hidup (SWLS) $(t=9.624, p=0.000 p<0.01)$ antara kelompok eksperimen dan kelompok kontrol Pada skala afeksi (PANAS) terdapat perbedaan yang signifikan antara kelompok eksperimen dan kelompok kontrol $(t=10.931, p=0.000 p<0.01)$.
\end{abstract}

Kata Kunci : pelatihan kebersyukuran; kesejahteraan subjektif, kepuasan hidup, afeksi, hipertensi

Salah satu penyakit degeneratif jadi masalah karena jumlah prevalesinya yang menjadi masalah kesehatan masya- yang tinggi dan cenderung meningkat rakat adalah hipertensi. Hipertensi men- ditiap tahunnya. Hipertensi sendiri 
merupakan istilah yang digunakan untuk tekanan darah tinggi yang menetap (Ramaiah, 2007). Setiawan dan Kusumawati (2014) mendefinisikan tekanan darah tinggi (hipertensi) adalah keadaan yang ditandai dengan terjadinya peningkatan tekanan darah di dalam arteri dan tekanan darah tersebut melebihi normal. Lidya (2009) menjelaskan bahwa hipertensi juga dikenal sebagai silent killer, hal tersebut dikarenakan para penderita hipertensi tidak menunjukkan gejala dan tanda-tanda manifestasi penyakit tersebut. Perjalanan penyakit hipertensi seringkali mengakibatkan keadaan yang berbahaya karena keberadaannya sering tidak disadari dan kerap tidak menimbulkan keluhan yang berarti hingga penyakit hipertensi tersebut tidak terkendali dan menimbulkan komplikasi ke jantung, otak, ginjal, mata, pembuluh darah, atau organ-organ vital lainnya (Setiawan \& Kusumawati, 2014). Hipertensi juga mampu meningkatkan resiko penyakit jantung koroner sebesar $12 \%$ dan meningkatkan resiko penyakit stroke sebesar 24\% (Setiawan \& Kusumawati, 2014).

Riset Kesehatan Dasar (2013) menyebutkan prevalensi hipertensi di Indonesia yang didapat melalui pengukuran pada umur $\geq 18$ tahun sebesar 25,8 persen dari seluruh jumlah penduduk Indonesia. Daerah Istimewa Yogyakarta sendiri memiliki prevalensi yang penderita hipertensi cukup tinggi yakni sebesar 25,7 persen. Setiawan dan Kusumawati (2014) menjelaskan prevalensi hipertensi di Indonesia diperkirakan 15 juta orang tetapi hanya $4 \%$ yang merupakan hipertensi terkontrol. Dengan demikian prevalensi hipertensi di Indonesia sebenarnya berpotensi memiliki jumlah yang lebih tinggi, Puskesmas Cangkringan sendiri mencatat kunjungan pasien hipertensi perbulannya rata-rata mencapai 50 hingga 70 pasien, jumlah tersebut meningkat setiap tahunnya pada 2014 tercatat 983 pasien sedangkan pada tahun 2015 hingga bulan maret kemarin telah tercatat 432 kunjungan pasien hipertensi. Berdasarkan data di atas berarti dapat disimpulkan bahwa dalam satu tahun ke depan jumlah penderita hipertensi akan meningkat sekitar 50\% dari tahun 2014 lalu.

Hipertensi pada umumnya tidak dapat sembuh dan bergantung pada obat seumur hidup (Setiawan \& Kusumawati, 2014). Dengan demikian, para penderita hipertensi selalu dibayang-bayangi dengan penyakit seumur hidup yang mengakibatkan keadaan yang berbahaya sewaktu-waktu dan dapat mengakibatkan kematian. Berdasarkan hasil wawancara dengan penderita hipertensi di Puskesmas Cangkringan, para penderita hiper- 
tensi menjelaskan bahwa mereka kaget dan mengkhawatirkan kondisi kesehatan mereka. Selain itu, diketahui pula bahwa para penderita hipertensi mengeluhkan produktivitas kerja mereka yang menurun, merasa cepat lelah, pundak cepat terasa pegal dan tegang, padahal menurut mereka kegiatan yang dilakukan tetaplah sama seperti dahulu.

Kesehatan sebagai salah satu prediktor kesejahteraan juga ditemui dalam beberapa penelitian, diketahui bahwa para penderita penyakit-penyakit kronis memiliki keluhan-keluhan terhadap dirinya, seperti merasa sedih, putus asa, pesimis, merasa diri gagal, tidak puas dalam hidup, merasa lebih buruk dibandingkan dengan orang lain serta merasa tidak berdaya. Penelitian lainnya mengenai penderita hipertensi yang dilakukan Anggraieni (2014) juga menemukan hal yang sama, bahwa para penderita hipertensi memiliki tingkat stres yang tinggi dan memilki banyak permasalahan sehari-hari baik fisik dan mental. Keluhan fisik tersebut seperti pening, sakit kepala kronis, peningkatan rasa dahaga, rasa mual, pandangan mata kabur, mimisan, telinga berdengung, dan detak jantung meningkat, sehingga penderita hipertensi akan mengalami kesulitan bernafas (sesak nafas) dan mudah mengalami kelelahan. Sedangkan permasalahan kesehatan men- tal sendiri seperti penurunan dimensi mental berupa gangguan psikologis seperti kegelisahan (berkaitan dengan tidur), dan kebugaran tubuh menurun karena energi tubuh yang dibutuhkan terkuras akibat sakit yang dirasakan sehingga tingkat kelelahan menjadi lebih besar dirasakan. Dengan demikian, para penderita hipertensi akan kehilangan semangat, memiliki emosi yang meledakledak, dan amarah yang tertekan (Taylor, 2009).

Kesejahteraan subjektif sendiri di dalam Islam dipandang pada dimensi sikap maupun perilaku manusia dalam menjalankan kehidupan sebagai mahkluk ciptaan Allah SWT. Al-Jauziyyah (2004) menjelaskan bahwa manusia diciptakan Allah sebagai makhluk yang terbentuk dari unsur akal dan syahwat. Manusia dapat menggunakan akalnya untuk memilah dan menentukan sikap perilaku serta menggelola syahwat yang dimiliki.

Lebih lanjut Al-Jauziyyah (2004) menjelaskan bahwa sikap dan perilaku manusia sehari-hari sebagai bentuk cinta seorang hamba kepada Allah sebagai penciptannya. Islam memandang rasa cinta kepada Allah SWT merupakan puncak kesempurnaan dan kebahagiaan seorang manusia yang diwujudkan dengan menanggung kesulitan demi ketaatan seorang hamba kepada Allah 
dan sebagai wujud keridhoan Allah (AlJauziyyah, 2004). Sesungguhnya cinta yang hakiki dan membuahkan hasil adalah cinta yang tetap tegar menghadapi berbagai hambatan, tantangan, dan gangguan. Sedangkan, cinta yang mensyaratkan (menuntut) kebahagiaan, kenikmatan, kesenangan, dan terpenuhinya keinginan sang pencinta dari yang dicinta, maka ini bukanlah cinta yang sejati (Al-Jauziyyah, 2004). Najati (1985) menjelaskan bahwa rasa cinta manusia kepada Allah dan kebahagiaan tentu saja didasari oleh iman, ketakwaan, beramal sholeh, dan mengikuti jalan Allah dalam kehidupannya.

Salah satu cara untuk meningkatkan kesejahteraan subjektif penderita hiper-tensi adalah dengan membekali sesuatu yang dapat membuat penderita hipertensi menerima keadaan mereka saat ini. Salah satu cara melalui pendekatan secara agama yakni nilai-nilai kebersyukuran. Handal (Utami, 2012) menemukan bahwa spiritualitas seseorang menurunkan pengaruh negatif stres. Agama mempunyai peranan penting dalam mengelola stres serta agama memberikan individu pengarahan, bimbingan, dukungan dan harapan dalam kehidupan (Utami, 2012). Hal tersebut sejalan dengan pendapat Seligman (2005) yang menyatakan bahwa agama merupakan harapan bagi seseorang yang mempercayainya. Individu yang mempunyai sikap religius akan mempercayai bahwa apapun yang dialaminya sudah ada yang mengatur, sehingga dapat menerima keadaan sesulit apapun dengan tulus, tanpa rasa marah maupun putus asa.

Bersyukur didefinisikan sebagai rasa berterima kasih dan bahagia sebagai respon penerimaan karunia, baik penerimaan tersebut merupakan keuntungan yang terlihat dari orang lain ataupun momen kedamaian yang ditimbulkan oleh keindahan alamiah (Seligman \& Peterson, 2005). Syukur menurut Alquran adalah ungkapan terima kasih atas nikmat yang telah diberikan, dengan jalan meng-gunakan nikmat-nikmat tersebut sebagai sarana beribadah kepada Allah SWT. Al-Jauziyyah (2004) menjelaskan bahwa dasar syukur adalah kebenaran tekad, oleh karena seorang hamba diperintah untuk mewujudkan kebenaran tersebut kedalam dirinya dan orang lain, yang mana hal tersebut tidak lain sebagai hakikat makna syukur. Keadaan yang ada pada tiap individu inilah yang menunjukkan sejauh mana individu tersebut dapata mensyukuri dengan sepenuh hati.

Emmons dan McCullough (2003) menunjukkan bahwa bersyukur memiliki 
keuntungan secara emosi dan inter- kebersyukuran untuk meningkatkan kesepersonal. Hal tersebut disebabkan pera- jahteraan subjektif penderita hipertensi.

saan syukur dapat menimbulkan emosi yang positif seperti ketenangan batin, METODE PENELITIAN hubungan interpersonal yang lebih nyaman, dan kebahagiaan. Lebih lanjut di jelaskan bahwa dengan bersyukur individu mampu menerima dengan ikhlas segala sesuatu yang terjadi dalam kehidupannya. Beberapa penelitian sebelumnya menunujukkan bahwa ada hubungan antara kebersyukuran terhadap kesejahteraan subjektif. Salah satunya penelitian yang dilakukan oleh Cahyareni (2014) diketahui bahwa pelatihan kebersyukuran dapat meningkatkan kesejahteraan subjektif pada pasien gagal ginjal kronik. Berdasarkan uraian di atas, peniliti akan melakukan pelatihan

\section{Desain Penelitian}

Penelitian ini merupakan penelitian quasi eksperimen dengan model rancangan penelitian yang akan digunakan adalah prates-pascates dan kelompok kontrol. Desain ini bertujuan untuk melihat efek suatu perlakuan terhadap kelompok yang diberi perlakukan dan kelompok yang tidak diberi perlakuan (kontrol) melalui beragam kriteria (seleksi) bukan acak (random). Pemilihan subjek ditetapkan dengan cara matching.

Desain penelitian ini dapat digambarkan sebagai berikut:

Tabel.1. Rancangan Eksperimen Penelitian

\begin{tabular}{lrccc}
\hline Kelompok & Prates & Perlakuan & Pascates & Tindak lanjut \\
\hline KE & Y1 & $\mathrm{X}$ & Y2 & Y3 \\
KK & Y1 & - & Y2 & Y3 \\
\hline
\end{tabular}

\section{Keterangan}

KE : Kelompok Eksperimen

KK : Kelompok Kontrol

Y1 : Pengukuran sebelum perlakuan (prates / pre-test)

Y2 : Pengukuran setelah perlakuan (pascates / post-test)

Y3 : Pengukuran tindak lanjut (follow-up)

$X$ : Perlakuan 


\section{Subjek Penelitian}

Subjek penelitian ini adalah penderita hipertensi laki-laki atau perempuan, berusia 40-60 tahun, beragama Islam dan memiliki variasi kesejahteraan subjektif rendah hingga tinggi. Dipilihnya usia dewasa madya dikarenakan pada usia ini merupakan usia dengan faktor resiko hipertensi terbesar serta usia dimana banyaknya stressor karena rentang usia perkembangan yang panjang.

\section{Metode Pengumpulan Data}

Penelitian ini menggunakan skala kesejahteraan subjektif pada penderita hipertensi. Skala pertama, yaitu The Satisfaction with Life Scale (SWLS) berdasarkan teori Diener, dkk (1985) yang terdiri dari 5 item dengan skor yang bergerak dari 1-7 (sangat tidak setuju hingga sangat setuju). Skala kedua, yaitu PANAS (Positive and Negative Afect Scale) untuk mengukur afek positif dan negatif terdiri dari 20 kata yang berkaitan dengan emosi dan atau perasaan. Skala ini dibuat oleh Watson, Clark \& Tellegen (1988) yang digunakan American Psychological Association (APA).

\section{Prosedur Penelitian}

Prosedur dalam penelitian ini meliputi beberapa tahapan penelitian. Perta- ma: Persiapan penelitian meliputi analisis kebutuhan terkait permasalahan dalam penelitian (wawancara dan studi pustaka) dan pengurusan perizinan. Kedua: Penyusunan modul pelatihan kebersyukuran. Materi pelatihan kebersyukuran berdasarkan teori dari Al-Jauziyyah (2005), yang terdiri dari bersyukur dengan hati, lisan dan perbuatan.

Ketiga: Pengambilan data prates pada subjek penelitian (kelompok eksperimen dan kelompok kontrol) dilakukan untuk mendapatkan gambaran mengenai kesejahteraan subjektif pada penderita hipertensi sebelum dilakukan pelatihan.

Keempat: Subjek penelitian sebanyak 12 orang (kelompok eksperimen) diberi pelatihan kebersyukuran dalam tiga kali pertemuan. Setiap pertemuan masing-masing berlangsung selama 90150 menit. Intervensi diberikan oleh pelatih atau psikolog yang berpengalaman memberikan intervensi keagamaan (Islam).

Kelima: Pengambilan pascates dilakukan setelah selesai dilaksanakan. Selanjutnya pengambilan data tindak lanjut dilakukan dua minggu setelah pelatihan. Tahapan terakhir adalah melakukan analisis secara keseluruhan. 


\section{Teknik Analisis Data}

Metode analisis data yang digunakan dalam penelitian ini adalah analisis data kuantitatif dan kualitatif. Analisis data kuantitatif dalam penelitian ini menggunakan program statistical product and service solution (SPSS) 16.0 for windows. Hipotesis penelitian diuji dengan menggunakan analisis parametric dengan teknik Independent sample $t$ test digunakan untuk menguji dua kelompok independen atau saling bebas yang ditarik dari suatu populasi (Susetyo, 2010).

\section{HASIL PENELITIAN}

\section{Deskripsi Subjek Penelitian}

Berikut ini penjelaskan dan deskripsi mengenai kepuasan hidup pada kelompok eksperimen yang diukur menggunakan SWLS.

Tabel. 2 Deskripsi data penelitian Kepuasan hidup (SWLS) Kelompok Eksperimen

\begin{tabular}{lcccccc}
\hline Subjek & JK & Prates & Pascates & $\begin{array}{c}\text { Tindak } \\
\text { Lanjut }\end{array}$ & $\begin{array}{c}\text { Gained } \\
\text { Score (Pra- } \\
\text { Pasca) }\end{array}$ & $\begin{array}{c}\text { Gained } \\
\text { Score (Pra- } \\
\text { Tindak } \\
\text { Lanjut) }\end{array}$ \\
\hline SUK & P & 11 & 22 & 22 & 11 & 11 \\
SRS & P & 15 & 24 & 26 & 9 & 11 \\
SUJ & P & 14 & 26 & 31 & 12 & 17 \\
NGA & P & 13 & 26 & 23 & 13 & 10 \\
SUM & P & 17 & 22 & 31 & 5 & 14 \\
TUM & P & 17 & 26 & 31 & 9 & 14 \\
MUJ & L & 18 & 26 & 26 & 8 & 8 \\
SUR & L & 19 & 30 & 27 & 11 & 8 \\
SAY & P & 15 & 30 & 28 & 15 & 13 \\
SRM & P & 20 & 28 & 26 & 8 & 20 \\
JUM & P & 21 & 28 & 31 & 17 & 13 \\
SRI & P & 14 & 28 & 27 & 14 & \\
\hline
\end{tabular}

Kelompok eksperimen semula ketiga. Dengan demikian subjek pada terdiri dari 13 subjek, namun sejalannya kelompok kontrol dalam penelitian pelatihan ada satu subjek dinyatakan menjadi berjumlah 12 subjek, yang gugur karena tidak hadir pada pertemuan terdiri atas 10 subjek berjenis kelamin 
perempuan dan dua subjek berjenis kelamin laki-laki. Berdasarkan tabel di atas, semua partisipan dalam penelitian ini mengalami peningkatan pada nilai kepuasan hidup. Peningkatan angka partisipan dari angka pada saat prates hingga tindak lanjut cukup beragam, antara lain terdapat delapan partisipan mengalami peningkatan $>10$ angka, tiga partisipan mengalami peningkatan $>5$ dan satu partisipan mengalami peningkatan sebesar 10 angka.

Tabel 3. Deskripsi data penelitian Kepuasan hidup (SWLS) Kelompok Kontrol

\begin{tabular}{llccccc}
\hline Subjek & JK & Prates & Pascates & $\begin{array}{c}\text { Tindak } \\
\text { Lanjut }\end{array}$ & $\begin{array}{c}\text { Gained } \\
\text { Score } \\
\text { (Pra- } \\
\text { Pasca) }\end{array}$ & $\begin{array}{c}\text { Gained } \\
\text { Score (Pra- } \\
\text { Tindak } \\
\text { Lanjut) }\end{array}$ \\
\hline NUA & P & 16 & 18 & 19 & 2 & 3 \\
ADS & $\mathrm{P}$ & 12 & 15 & 14 & 3 & 2 \\
KAR & $\mathrm{P}$ & 16 & 16 & 14 & 0 & -2 \\
IYT & $\mathrm{P}$ & 12 & 11 & 13 & -1 & 1 \\
PYO & $\mathrm{L}$ & 19 & 17 & 14 & -2 & -5 \\
NOT & $\mathrm{L}$ & 12 & 13 & 16 & 1 & 4 \\
INN & $\mathrm{P}$ & 14 & 13 & 15 & -1 & 1 \\
HRD & $\mathrm{L}$ & 17 & 13 & 16 & -4 & -1 \\
YAK & $\mathrm{P}$ & 15 & 15 & 17 & 0 & 2 \\
TKN & $\mathrm{P}$ & 15 & 15 & 13 & 0 & -2 \\
HRT & $\mathrm{P}$ & 19 & 16 & 13 & -3 & -6 \\
\hline
\end{tabular}

Pada tabel di atas diketahui bahwa kelompok kontrol yang berjumlah 11 orang, yang terdiri atas tiga orang lakilaki dan delapan orang perempuan. Berdasarkan tabel di atas diketahui bahwa terdapat perbedaan yang sangat jelas pada angka kepuasan hidup para partisipan. Angka yang didapatkan pada saat prates dengan angka tindak lanjut, diketahui terdapat empat partisipan mengalami peningkatan angka afeksi dan tujuh partisipan yang mengalami penurunan angka kepuasan hidup. 
Tabel.4. Deskripsi data penelitian Skala Afek (PANAS) Kelompok Eksperimen

\begin{tabular}{lcccccc}
\hline Subjek & JK & Prates & Pascates & $\begin{array}{c}\text { Tindak } \\
\text { Lanjut }\end{array}$ & $\begin{array}{c}\text { Gained } \\
\text { Score } \\
\text { (Pra- } \\
\text { Pasca) }\end{array}$ & $\begin{array}{c}\text { Gained } \\
\text { Score (Pra- } \\
\text { Tindak } \\
\text { Lanjut) }\end{array}$ \\
\hline SUK & P & -6 & 18 & 16 & 24 & 22 \\
SRS & $\mathrm{P}$ & -4 & 11 & 11 & 15 & 15 \\
SUJ & $\mathrm{P}$ & -5 & 21 & 14 & 26 & 19 \\
NGA & $\mathrm{P}$ & -6 & 8 & 18 & 14 & 24 \\
SUM & $\mathrm{P}$ & -5 & 22 & 16 & 27 & 21 \\
TUM & $\mathrm{P}$ & -3 & 20 & 15 & 23 & 18 \\
MUJ & $\mathrm{L}$ & -4 & 18 & 28 & 22 & 32 \\
SUR & $\mathrm{L}$ & -2 & 19 & 30 & 21 & 32 \\
SAY & $\mathrm{P}$ & -7 & 8 & 19 & 15 & 26 \\
SRM & $\mathrm{P}$ & -5 & 9 & 13 & 14 & 18 \\
JUM & $\mathrm{P}$ & -9 & 23 & 23 & 32 & 32 \\
SRI & $\mathrm{P}$ & -4 & 19 & 25 & 23 & 29 \\
\hline
\end{tabular}

Pada tabel di atas, tampak bahwa $>20$ angka dan sebanyak empat seluruh partisipan kelompok eksperimen partisipan mengalami peningkatan $>30$ mengalami peningkatan nilai afeksi pada angka. Namun, berdasarkan tabel di atas, saat dilakukan pengukuran pada tindak diketahui pada angka pascates dan tindak lanjut. Terdapat empat partisipan yang lanjut terdapat beberapa partisipan yang mengalami peningkatan $>10$ angka dan mengalami penurunan angka, yakni lima peserta mengalami peningkatan sejumlah emapt partisipan. 
Tabel.5. Deskripsi data penelitian skala Afek (PANAS) Kelompok Kontrol

\begin{tabular}{|c|c|c|c|c|c|c|}
\hline Subjek & JK & Prates & Pascates & $\begin{array}{l}\text { Tindak } \\
\text { Lanjut }\end{array}$ & $\begin{array}{l}\text { Gained } \\
\text { Score } \\
\text { (Pra- } \\
\text { Pasca) }\end{array}$ & $\begin{array}{c}\text { Gained } \\
\text { Score (Pra- } \\
\text { Tindak } \\
\text { Lanjut) }\end{array}$ \\
\hline NUA & $P$ & -4 & -2 & 0 & 2 & 4 \\
\hline ADS & $P$ & -6 & 0 & 1 & 6 & 7 \\
\hline KAR & $P$ & -3 & 1 & 2 & 4 & 5 \\
\hline IYT & $\mathrm{P}$ & -4 & -3 & -3 & 1 & 1 \\
\hline PYO & L & -5 & -3 & -4 & 2 & 1 \\
\hline NOT & L & 1 & -1 & -2 & -2 & -3 \\
\hline INN & $\mathrm{P}$ & -8 & -2 & -2 & 6 & 6 \\
\hline HRD & $\mathrm{L}$ & 2 & 2 & 2 & 0 & 0 \\
\hline YAK & $P$ & -6 & -3 & -4 & 3 & 2 \\
\hline TKN & $\mathrm{P}$ & -2 & -1 & -4 & 1 & -2 \\
\hline HRT & $\mathrm{P}$ & -3 & -3 & -2 & 0 & 1 \\
\hline
\end{tabular}

Tabel di atas menjelaskan angka afeksi pada kelompok kontrol, terdapat tujuh partisipan mengalami peningkatan angka afeksi pada saat tindak lanjut dan dua partisipan mengalami penurunan angka afeksi.

\section{Hasil Uji Asumsi}

Rangkuman hasil uji normalitas dapat dilihat pada tabel di bawah ini:

Tabel 6. Uji Normalitas Skala Kepuasan Hidup (SWLS)

\begin{tabular}{cccc}
\hline Kelompok & Perlakuan & $\mathbf{P}$ & Keterangan \\
\hline Eksperimen dan & Prates & $0.200 ;$ & Normal \\
Kontrol & & $\mathrm{p}>0.05$ & \\
\hline
\end{tabular}

Berdasarkan tabel di atas, diketahui hasil sebaran skor kepuasan hidup pada penelitian ini mengikuti distribusi secara normal. Adapun normalitas pada pada skala afek positif dan afek negatif (PANAS) sebagai berikut: 
Tabel 7. Uji Normalitas Skala Afek (PANAS)

\begin{tabular}{cccc}
\hline Kelompok & Perlakuan & P & Keterangan \\
\hline Eksperimen dan & Prates & $0.163 ;$ & Normal \\
Kontrol & & $\mathrm{p}>0.05$ & \\
\hline
\end{tabular}

Pada tabel di atas diketahui bahwa dilakukan, jika $p>0.05$ maka variabel hasil sebaran skala afeksi (PANAS) terdistribusi normal. bertistribusi normal. Kaidah uji yang

Tabel 8. Uji Homogenitas data Penelitian Skala Kepuasan Hidup (SWLS)

\begin{tabular}{cccc}
\hline Kelompok & Levene Statistic & $\mathbf{P}$ & Keterangan \\
\hline $\begin{array}{c}\text { Prates Eksperimen } \\
\text { dan Kontrol }\end{array}$ & 0.355 & $0.558 ; \mathrm{p}>0.05$ & Homogen \\
\hline
\end{tabular}

Pada tabel uji homogenitas pada skala kepuasan hidup (SWLS) menunjukkan nilai Levene Statistic 0.355 dengan $p=0.558 \quad(p>0.05)$. Dengan demikian dapat diartikan bahwa tidak ada perbedaan varians data pada saat prates kelompok eksperimen dan kontrol pada subjek penelitian atau homogen.

Berikut hasil uji homogenitas skala afek positif dan afek negatif kelompok eksperimen dan kelompok kontrol.

Tabel 9. Uji Homogenitas Data Penelitian Skala Afek (PANAS)

\begin{tabular}{cccc}
\hline Kelompok & Leven Statistic & P & Keterangan \\
\hline $\begin{array}{c}\text { Prates Eksperimen } \\
\text { dan Kontrol }\end{array}$ & 0.880 & $0.180 ; \mathrm{P}>0.05$ & Homogen \\
\hline
\end{tabular}

Pada tabel hasil uji homogenitas skala afek positif dan afek negatif (PANAS) menunjukkan nilai Levene Statistic 1.905 dengan $P=0,180$ $(\mathrm{P}>0.05)$. Dengan demikian, maka dapat dikatakan bahwa tidak ada perbedaan varians data pada saat prates kelompok eksperimen dan kontrol pada subjek penelitian. 
Hasil Uji Hipotesis

Berikut adalah hasil uji beda (independent sample $t$ test) gain score antara kelompok eksperimen dan kelompok kontrol:

Tabel 10. Data Perbandingan Hasil Uji Hipotesis Skala Kepuasan Hidup

\begin{tabular}{lccc}
\hline \multicolumn{1}{c}{ Perhitungan } & T & Sig. (p) & Kesimpulan \\
\hline Selisih skor Prates-pascates & 9.624 & 0.000 & Signifikan \\
Selisih skor Prates- Tindak Lanjut & 8.149 & 0.000 & Signifikan \\
\hline
\end{tabular}

Pada tabel hasil uji hipotesis di atas, diketahui bahwa terdapat perbedaan kepuasan hidup yang sangat signifikan pada kelompok eksperimen dan kelompok kontrol pada saat sebelum dan setelah pelatihan kebersyukuran $(\mathrm{t}=$ 9.624; $\mathrm{p}=0.000, \mathrm{p}<0.01)$. Selanjutnya, pada saat dilakukan tindak lanjut, terdapat perbedaan yang sangat signifikan antara kelompok eksperimen dan kelompok kontrol $(\mathrm{t}=8.149 ; \mathrm{p}=0.000$, dan $\mathrm{p}<0.01)$. Hal tersebut dapat disimpulkan bahwa kelompok eksperimen memiliki perbedaan kepuasan hidup yang signifikan setelah diberikan pelatihan kebersyukuran. Dengan demikian pelatihan kebersyukuran berpengaruh terhadap peningkatan kepuasan hidup para penderita penyakit hipertensi.

Tabel 11. Data Perbandingan Hasil Uji hipotesis Skala Afek (PANAS)

\begin{tabular}{lccc}
\hline \multicolumn{1}{c}{ Perhitungan } & T & Sig. (p) & Kesimpulan \\
\hline Selisih skor Prates-pascates & 10.931 & 0.000 & Signifikan \\
Selisih skor Prates- Tindak Lanjut & 11.303 & 0.000 & Signifikan \\
\hline
\end{tabular}

Hasil uji t-test pada perubahan nilai afeksi kelompok eksperimen dan kelompok kontrol pada prates dan pascates yakni $\mathrm{t}=10.931, \mathrm{p}=0.000$ $(p<0.01)$. Hasil menunjukkan bahwa terdapat perbedaan yang signifikan skor afeksi pada kelompok eksperimen dan kelompok kontrol sebelum dan sesudah diberikan pelatihan kebersyukuran. Pada saat tindak lanjut, terdapat perbedaan yang signifikan pula antara kelompok eksperimen dan kelompok kontrol $(\mathrm{t}=$ 11.303, $\mathrm{p}=0.000, \mathrm{p}<0.01$ ). Dengan demikian, pelatihan kebersyukuran berpengaruh signifikan pada skor afeksi 
pada subjek penelitian hingga masa tindak lanjut berkahir.

\section{PEMBAHASAN}

Penelitian ini bertujuan untuk mengetahui efektivitas pelatihan kebersyukuran terhadap peningkatan kesejahteraan subjektif para penderita hipertensi. Hasil yang diperoleh dalam penelitian ini menunjukkan bahwa pelatihan kebersyukuran berpengaruh dalam peningkatan kesejahteraan subjektif pada penderita hipertensi. Hasil penelitian menunjukkan bahwa terjadi perbedaan rerata gain score kesejahteraan subjektif setelah diberi perlakuan berupa pelatihan kebersyukuran pada kelompok eksperimen dan kelompok kontrol yang tidak diberikan perlakuan pada penderita hipertensi. Berdasarkan analisis data yang dilakukan pada kesejahteraan subjektif penderita hipertensi menunjukkan bahwa terdapat perbedaan kesejahteraan subjektif antara kelompok eksperimen yang diberikan perlakuan berupa pelatihan kebersyukuran dengan kelompok kontrol yang tidak diberikan perlakuan berupa pelatihan kebersyukuran pada penderita hipertensi.

Berdasarkan hasil analisis uji beda, ditemukan perubahan pada nilai kepuasan hidup (SWLS) diketahui bahwa ter- dapat perubahan yang signifikan pada saat sebelum dilaksanakan pelatihan kebersyukuran dan setelah pelatihan (prapasca), antara kelompok eksperimen dan kelompok kontrol dengan $\mathrm{t}=9.624 ; \mathrm{p}=$ 0.000 ( $p<0.01$ ). Selanjutnya, pada saat sebelum pelaksanaan pelatihan kebersyukuran dan pada saat tindak lanjut (pratindak lanjut) didapat nilai $\mathrm{t}=8.149 ; \mathrm{p}$ $=0.000$, dan $p<0.01$. Hal tersebut menunjukkan bahwa ada perbedaan tingkat kepuasan hidup para penderita hipertensi yang sangat signifikan antara kelompok eksperimen dan kelompok kontrol.

Pada skala afeksi (PANAS) hasil analisis uji beda menemukan perubahan nilai afeksi kelompok eksperimen dan kelompok kontrol pada prates dan pascates, yakni $\mathrm{t}=10.931, \mathrm{p}=0.000$ $(p<0.01)$. Hal tersebut menunjukkan bahwa ada perbedaan yang signifikan antara kelompok eksperimen dan kelompok kontrol sebelum dan setelah pelaksanaan pelatihan kebersyukuran. Selanjutnya, pada analisis uji beda menemukan adanya perbedaan sebelum (prates) dan pada saat tindak lanjut, dengan nilai $t=11.303, p=0.000,(p$ $<$ 0.01). Hal tersebut menunjukkan ada perbedaam yang signifikan terhadap tingkat afeksi penderita hipertensi antara kelompok eksperimen dan kelompok 
kontrol pada saat dilakukannya tindak lanjut.

Berdasarkan hasil analisis skala kepuasan hidup, terdapat 4 orang partisipan yang mengalami peningkatan skor nilai sangat signifikan berdasarkan skor kepuasan hidup kelompok eksperimen. Hal tersebut dikarenakan setelah mendapatkan pelatihan kebersyukuran para partisipan dapat lebih mudah memahami dan memaknai hal-hal yang perlu disyukuri di dalam hidupnya. Para partisan menyadari bahwa banyak hal-hal kecil maupun besar di dalam kehidupan sehari-harinya yang perlu untuk disyukuri. Para partisipan juga mengetahui bentuk-bentuk sederhana dalam bersyukur atas nikmat yang diberikan Allah SWT.

Pelatihan kebersyukuran diberikan dalam suatu intervensi kelompok sehingga dapat mempermudah tercapainya tujuan dari penelitian ini. Setting kelompok yang dilakukan pada penelitian ini memungkinkan para partisipan untuk menciptakakan hubungan interpersonal yang sangat dekat, sehingga terbentuknya suasana saling percaya, memahami, terbuka, berbagi permasalahan yang dirasakan, empati, umpan balik dan afirmasi positif. Para partisipan pun dapat saling berbagi dan membandingkan pengalaman-pengalaman maupun kondi- si yang dialaminya dengan partisipan lainnya. Proses ini dirasa sangat bermanfaat untuk meningkatkan rasa kebersyukuran antar anggota partisipan. Hal tersebut sejalan dengan penelitian ElBantanie (2014) dimana individu akan semakin mudah untuk bersyukur pada saat membandingkan kondisi diri dengan orang lainnya.

Plante (2009) menjelaskan bahwa kebersyukuran merupakan salah satu dari bentuk spiritual dan religiusitas yang digunakan sebagai bentuk intervensi. Pada intervensi kebersyukuran kali ini mengandung edukasi atau penjelasan mengenai materi pada setiap pertemuan menggunakan media gambar, tulisan maupun video. Desain penelitian ini menggunakan aktivitas-aktivitas pembelajaran melalui pengalaman (Experiental Learning), yakni pembelajaran melalui pengalaman. Proses pembelajaran menjadi efektif karena individu mendapatkan stimulasi yang berulang melalui berbagai indera, baik penglihatan, pendengaran, pengecapan, penciuman dan perabaan (Johnson dan Johnson, 2009). Pada penelitian ini, partisipan diberikan tugastugas harian berupa latihan bersyukur di dalam kehidupan sehari-hari yang berguna dalam meningkatkan rasa syukur para partisipan. Hal tersebut sejalan dengan penelitian Emmons dan Mc- 
Cullough (2003) yang menemukan bahwa individu yang menuliskan hal-hal yang disyukuri memiliki tingkat kesejahteraan subjektif lebih tinggi. Ditambahkan pula, Fabricatore dan Handal (Utami, 2012) menemukan bahwa seseorang yang memiliki spiritualitas yang baik dan memiliki hubungan langsung dengan tuhan dapat mengurangi pengaruh negatif stres pada kepuasan hidupnya.

Sesi lain dalam pelatihan kebersyukuran ini juga menggunakan sesi pemaknaan positif, sehingga setiap partisipan diberikan kesempatan untuk memaknai setiap peristiwa yang dialaminya setiap hari dan membagikannya pada saat pelatihan. Pertukaran pemaknaan maupun masukan dari sesama partisipan pelatihan kebersyukuran ini juga sangat dirasakan bermanfaat dan membantu para partisipan dalam mewujudkan rasa bersyukur dalam setiap peristiwa seharihari. Kebanyakan orang memandang rasa syukur hanya kepada sesuatu yang baik atau sesuatu di luar pengalaman seharihari yang membuatnya merasa kagum, maupun hal-hal yang dirasa tidak dapat dilupakan. Seseorang tidak terbiasa bersyukur ketika sedang di tengah kesulitan atau konflik, atau ketika impian tidak tercapai. Hal tersebutlah yang membuat keberyukuran terlihat hanya digunakan pada saat kondisi menyenangkan (Miller, 2010). Padahal kebersyukuran merupakan hal yang harus dimiliki dan menetap dalam diri seseorang dan diperaktikan ketika seseorang berada pada situasi baik maupun situasi buruk. Lebih lanjut al-Jauziyyah (2005) menjelaskan Allah memberikan cobaan kepada hambanya berupa nikmat sebagaimana Allah memberikan cobaan kepada hamba-Nya berupa musibah, cobaan tersebut hakikatnya adalah untuk menguji manusia untuk bersyukur dalam keadaan lapang maupun keadaan sempit.

Secara kualitatif para partisipan juga menjelaskan bahwa mereka merasa lebih puas dengan kehidupan yang dimilikinya saat ini. Para partisipan menjelaskan bahwa mereka dapat melihat segala yang dimiliki dengan lebih positif. Jackowska, Brown, Ronaldson, dan Steptoe (2015) menjelaskan dengan mengekpresikan kebersyukuran dapat meningkatkan rasa optimisme terhadap kehidupan. Para partisipan menjelaskan bahwa mereka lebih positif dan yakin dalam memandang hari-hari kedepannya dan dampak yang paling dirasakan oleh para partisipan adalah berkurangnya emosi-emosi negatif seperti, marah dan berkurangnya perasaan khawatir atau cemas. McCullough, Emmons dan Tsang (Sheldon \& Lyubomirsky, 2006) men- 
jelaskan bahwa melatih rasa syukur akan berlawanan dengan emosi-emosi negatif, sehingga dapat menghambat munculnya perasaan marah, iri, maupun rasa kepahitan. Sejalan dengan hal tersebut, Lai (2014) menemukan bahwa orang-orang yang bersyukur memiliki emosi negatif yang lebih rendah dan memiliki keluhankeluhan fisik yang rendah pula. Hal tersebut sesuai dengan temuan pada para partisipan pelatihan kebersyukuran. Para partisipan merasakan berkurangnya keluhan-keluhan sakit fisik seperti, pusing, pundak tegang, maupun keluhan fisik lainnya.

Berdasarkan hasil data kualitatif diketahui pula bahwa kemampuan subjek terhadap peningkatan kesejahte-raan subjektif pun berbeda-beda. Hal tersebut terlihat dari peningkatan nilai kepuasan hidup dan afeksi yang berbeda setiap partisipan. Perbedaan tersebut dipengaruhi oleh perbedaan setiap partisipan dalam memaknai rasa syukur dan menyerap materi-materi pelatihan dan proses belajar yang berbeda pada setiap partisipan.

Keberhasilan pelatihan kebersyukuran ini dipengaruhi oleh beberapa faktor penting yakni, modul, pelatih, partisipan, dan fasilitas (Anggraeini, 2014). Pelatih dalam pelatihan kebersyukuran mempermudah pemahaman partisipan terhadap materi yang disampaikan. Pelatih memberikan pemahaman dengan menggunakan bahasa yang mudah dipahami oleh para partisipan. Pelatih juga memberikan contoh-contoh yang rill sesuai dengan kondisi dan keadaan para partisipan sehari-hari.

Keberhasilan pelatihan ini juga didukung oleh antusiasme, motivasi, dan penerimaan yang baik dari partisipan. Hal tersebut terlihat dari kehadiran seluruh partisipan yang tepat waktu, partisipan yang aktif dalam berpendapat, dan memberikan umpan balik. Hal tersebut didukung berdasarkan hasil evaluasi pelatihan kebersyukuran menambahkan ilmu, informasi dengan seluruh materi yang diberikan, sehingga lebih termotivasi untuk menjalankan pengobatan dan pola hidup yang lebih sehat. Para peserta terdorong untuk membiasakan diri untuk mengutamakan pikiran dan perasaan positif untuk membiasakan diri mengutamakan pikiran positif dan perasaan positif dengan selalu bersyukur pada setiap kondisi apapun.

Pada analisis tambahan, tekanan darah para penderita hipertensi yang diberikan intervensi pelatihan kebersyukuran dengan yang tidak diberikan intervensi pelatihan kebersyukuran tidak ada perbedaan yang signifikan. Pada saat prates-pasca tes, pada tekanan darah 
sistolik diketahui nilai $\mathrm{t}=-1.430$, $\mathrm{p}=0.167, \quad \mathrm{p}>0.01$ dan pada tekanan darah diastolik nilai $\mathrm{t}=0.168, \mathrm{p}=0.868$, $p>0.01$. Pada saat prates-pascates, tekanan darah sistolik didapat nilai $\mathrm{t}=-$ 2.056, $\mathrm{p}=0.052, \mathrm{p}>0.01$ dan pada tekanan darah diastolik $t=1.858$, $p=0.077, p>0.01$. Hal tersebut menunjukkan bahwa tidak ada perbedaan tekanan darah sistolik maupun diastolik pada saat prates-pascates pada penderita hipertensi yang diberikan pelatihan kebersyukuran ataupun penderita hipertensi yang tidak diberikan pelatihan kebersyukuran.

Bianci, Birkenhager, Stasen dan Wang (2003) menjelaskan bahwa tekanan darah dipengaruhi dengan oleh banyak faktor antara lain, gaya hidup, pola makan dengan asupan garam tinggi, dan perilaku merokok. Dengan demikian, tekanan darah juga dapat menjadi tidak stabil disebabkan kondisi yang tidak nyaman yang muncul tibatiba, seperti ketakutan pada saat subjek akan diukur tekanan darah ataupun makanan yang subjek konsumsi sebelumnya. Sejalan dengan hal tersebut, Meliala (Fatimah, 2009) menjelaskan bahwa banyak faktor yang dapat mempengaruhi seperti faktor perilaku, faktor kognitif, faktor psikologik dan faktor fisiologik. Aktivitas yang dilakukan subjek sebelum dilakukannya pengukuran tekanan darah, juga dapat mempengaruhi tekanan darah seseorang. Meliala (Fatimah, 2009) menambahkan bahwa hipertensi bersifat sangat subjektif sehingga tekanan darah masing-masing individu menjadi sangat bervariasi.

Penelitian ini juga memiliki beberapa kekurangan, seperti penilaian tekanan darah tidak dilakukan pada setiap kali sesi, sehingga pengukuran tekanan darah hanya dilihat pada saat prates, pasca tes dan tindak lanjut. Selain itu, penelitian ini berbentuk intervensi kelompok, sehingga pelatihan kebersyukuran ini lebih efektif diberikan kepada individu yang memiliki kemampuan komunikasi yang aktif. Sedangkan pada saat penentuan subjek penelitian penulis menentukan berdasarkan kategorisasi kesejahteraan subjektif dan kebersediaan subjek untuk ikut serta dalam pelatihan.

\section{SIMPULAN DAN SARAN}

\section{Simpulan}

Pertama, hasil penelitian ini membuktikan bahwa terdapat peningkatan nilai kepuasan hidup pada penderita hipertensi yang mendapatakan intervensi berupa pelatihan kebersyukuran dibandingkan dengan penderita hipertensi yang tidak diberikan intervensi pelatihan 
kebersyukuran. Kedua, terdapat peningkatan yang siginifikan pada nilai afeksi pada penderita hipertensi yang diberikan intervensi pelatihan kebersyukuran dibandingkan dengan penderita hipertensi yang tidak diberikan intervensi pelatihan kebersyukuran. Ketiga terdapat perbedaan nilai kesejahteraan subjektif pada penderita hipertensi yang diberikan intervensi pelatihan kebersyukuran dibandingkan dengan kelompok penderita hipertensi yang tidak diberikan intervensi pelatihan kebersyukuran.

\section{Saran}

Saran untuk penelitian selanjutnya dapat meneliti efektivitas pelatihan kebersyukuran tidak hanya bagi penderita hipertensi, namun juga dapat dilakukan pada tahap perkembangan lainnya, maupun penyakit-penyakit lainnya. Selain itu, pada penelitian selanjutnya juga diharapkan agar pelatihan kebersyukuran ini dapat digunakan untuk meningkatkan variabel lainnya, seperti penerimaan diri dan resiliensi.

Manfaat dalam penelitian ini juga dapat menjadi masukan bagi setiap pusat layanan kesehatan dalam meningkatkan kesejahteraan subjektif para penderita hipertensi. Dengan demikian, diharapkan pihak puskesmas dapat memberikan pelatihan ataupun kegiatan yang ber- kelanjutan bagi para penderita hipertensi lainnya di wilayah Cangkringan.

\section{DAFTAR PUSTAKA}

Al-Jauziyyah., I.Q. (2004). Kunci kebahagiaan. Jakarta: Akbar.

Al-Jauziyyah, I.Q. (2005). Mukhtasar: 'Uddah al-sābirīn wa dakhïrah alshākirīn (Perisai orang-orang sabar dan bersyukur). Edisi Indonesia. Solo: Pustaka Arafah.

Anggraieni, W. N. (2014). Pengaruh terapi relaksasi dzikir untuk menurunkan stres pada penderita hipertensi esesnsial. Thesis (Tidak diterbitkan). Magister Psikologi Profesi Universitas Islam Indonesia.

Bianci, G. Birkenhager, W.H., Stasen, J.A., \& Wang, J. (2003). Essential hypertension. The Lancet.

Cahyareni, L. (2014). Pelatihan kebersyukuran dengan metode dzikir untuk meningkatkan subjective well being pada penderita gagal ginjal kronik. Tesis (Tidak diterbitkan). Magister Psikologi Profesi. Universitas Islam Indonesia.

Diener, E., Emmons, R.A., Larsen, R.J \& Griffin, S., (1985). The satisfaction with life Scale. Journal of 
personality Assessment, (49) 1, 7175.

El-Bantanie, M. S. 2014. Sabar Tanpa Batas, Syukur Tanpa Ujung. Jakarta: PT. Gramedia.

Emmons, R.A. \& McCullough, M. E. (2003). Counting blessings versus burdens: An experimental investigation of gratitude and subjective well-being in daily life. Journal of Personality and Social Psychology, 84(2), 377-389.

Fatimah, A. (2009). Pengaruh logoterapi terhadap hipertensi pada pasien lanjut usia. Thesis (Tidak diterbitkan). Fakultas Kedokteran Universitas Sebelas Maret.

Jackowska, M. Brown, J. Ronaldson, A \& Steptoe, A. (2015). The impact of a brief gratitude intervention on subjective well-being, biology and sleep. University College London, UK.

Johnson, D.W., Johnson, F,P. (2009). Joining together: Group theraphy and group skills. $9^{\text {th }} \mathrm{Ed}$. New Jersey: Person Education Inc.

Lai T, S. (2014). The efficacy of gratitude practice on well being: A randomized controlled trial. Thesis (tidak diterbitkan ). Psychology,
School of Natural Science. University of Stirling.

Lidya, H.A. (2009). Studi prevalensi dan determinan hipertensi di propinsi kepulauan bangka belitung tahun 2007: Analisis riset kesehatan dasar 2007. Skripsi (Tidak diterbitkan). Fakultas Kesehatan Masyarakat. Universitas Indonesia.

Linley, P. Alex. Dan Stephen Joseph. (2004). Positive psychology in practice. New Jersey: John Wiley\&Sons, inc.

McCullough, M.e.,Emmons, R,A.,\& Tsang. J.A. (2002). The grateful disposition: A conceptual and empirical topography. Journal of Personality and Social Psychology, 82, 112-127.

Miller, M.R. (2010). A guide to spiritual practice. Stanford: CREDO instintute, Inc.

Najati, M. U.(1985). Al Quran dan ilmu jiwa. Bandung: Pustaka.

Newman, B. M., Newman, P.R., LandryMeyer, L., \& Loham, B.J. (2003). Life span development, a case book. Ontorio: Thomson Learning, Inc.

Plante, T. G. (2009). Spiritual practice in psychoterapy: Thirteen tools for 
enchancing psychological health. Washington DC: American Psychological Association Spiritual Practice.

Ramaiah,S. (2007). Hipetensi. Jakarta: Bhuana.

Riset Kesehatan Dasar, 2013. Jakarta: Badan Penelitian dan Pengembangan Kesehatan. Kementerian Kesehatan RI.

Setiawan, M. B., Kusumawati, P, D. (2014). Pengaruh penyuluhan kesehatan tentang pengobatan non farmakologi terhadap perilaku penderita hipertensi dalam melaksanakan pengobatan non farmakologi di Puskesmas Sampung Kabupaten Ponorogo. Jurnal Strada, 4(2), 42-51.

Seligman, M., Steen, T.A., Park, N., \& Peterson, C. (2005). Positive psychology progress: Empirical validation of interventions. The
American Psychologist, 60(5), 410421.

Sheldon, K.M., \& Lyubomirsky, S. (2006). How to increase and sustain positive emotion: The effect of expressing gratitude and visualizing best possible selves. The Journal of Positive Psychology, 1(2). 73-82.

Taylor, S. E. (2009). Health psychology. $7^{\text {th }}$ edition Mc Graw Hill. Singapore.

Utami, M,S. (2012). religiusitas, koping religius, dan kesehatan subjektif. Jurnal Psikologi, 39(1), 46-66.

Watson, D.W., Clark, L.A., \& Tellegen, A. (1988). Development and validation of brief measures of positive and negative affect: The PANAS scales. Journal of Personality and Social Psychology, 54(6), 1063 - 1070. 